\title{
Comparative studies of fibres of woody species selected in relation to their paper-making potentials
}

\section{Estudios comparativos de fibras de especies de madera seleccionadas en relación con sus potenciales de hacer papel}

\author{
Godswill C. Ajuziogu', Eugene O. Ojual', Ngozi E. Abu', Christopher C. Onyeke', Virginus O. Ayogu', \\ Anthony E. Nwezel and Solomon Nworiel
}

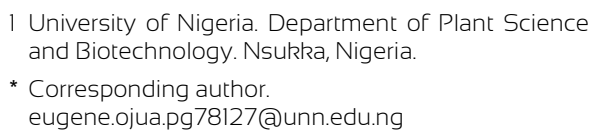

* Corresponding author.

eugene.ojua.pg78127@unn.edu.ng

\begin{abstract}
The wood fibre used by the paper industry originates primarily from forests. Apart from Gmelina arborea, there are other fast-growing plant species whose fibre characteristics are yet unknown. In order to relieve the pressure and demand on $G$. arborea, this work was aimed at characterizing and comparing the fibres of four tree species (Parkia biglobosa, Arzadiracbta indica, Alstonia boonei and Cassia siamea) to G. arborea, with the intention of elucidating their suitability for the pulp and paper industry. The trunk wood samples used in this study were collected from the Botanical Garden of the University of Nigeria, Nsukka, while the study was conducted in the Plant Anatomy Laboratory in the Department of Plant Science and Biotechnology, University of Nigeria, Nsukka, Enugu State-Nigeria. The results showed that the mean fibre length ranged from $1.00 \mathrm{~mm}$ in P. biglobosa to $1.70 \mathrm{~mm}$ in $A$. boonei. The fibre lengths of $G$. arborea and $A$. booneidid do not vary significantly $(\mathrm{P}<0.05)$. The Runkel ratio ranged from 0.624 to 3.227 across the species with $G$. arborea and $A$. boonei recording the lowest values. Conclusively, $A$. boonei is another pulp wood with good paper-making potential that could substitute the already known G. arborea.
\end{abstract}

KEYWORDS: Alstonia boonei; fibre; Gmelina arborea; Nigeria; papermaking; pulp wood.

\section{RESUMEN}

Las fibras de la madera usadas en la industria del papel tienen su origen en los bosques. Además de Gmelina arborea, existen otras especies de rápido crecimiento, cuyas características de fibras aún son desconocidas. Con el fin de aligerar la presión y la demanda de G. arborea, este trabajo tuvo como objetivo caracterizar y comparar las fibras de cuatro especies (Parkia biglobosa, Arzadiracbta indica, Alstonia boonei y Cassia siamea) con las de G. arborea, en cuanto a su idoneidad para la industria de la pulpa y el papel. Las muestras de madera utilizadas en este estudio fueron colectadas en el jardín botánico de la Universidad de Nigeria, Nsukka; el estudio se llevó a cabo en el Laboratorio de Anatomía de las Plantas en el Departamento de Ciencias de la Plantas y Biotecnología, Universidad de Nigeria, Nsukka, Enugu StateNigeria. Los resultados mostraron que la longitud media de la fibra varió desde $1.00 \mathrm{~mm}$ en $P$. biglobosa hasta $1.70 \mathrm{~mm}$ en $A$. boonei. Las longitudes de las fibras de G. arborea y $A$. boonei no variaron significativamente $(\mathrm{P}<0.5)$. La relación de Runkel varió de 0.624 a 3.227 entre las especies, con $G$. arborea y $A$. boonei registrando los valores más bajos. Se concluyó que $A$. boonei es otra especie que proporciona pulpa con buen potencial para hacer papel, pudiendo sustituir a la ya conocida G. arborea.

Palabras Clave: Alstonia boonei; fibra; Gmelina arborea; Nigeria; fabricación de papel; pulpa de madera. 


\section{INTRODUCTION}

Paper as an end-user product has proven to be critical in driving most sensitive needs of mankind, remarkably in areas of security, education, sanitation, and communication (Ezeudu, Agunwamba, Ezeasor, \& Madu, 2019). Paper is made from fibrous materials, whereby the most recent economical source of fibre is wood. The wood fibre used by the paper industry originates primarily from plantation forests (Ervasti, 2016). However, fibre raw material in paper production can be classified into two main pulp categories; virgin wood pulps produced from primary wood fibres and recycled fibre pulps generated from recycling of materials. Non-fiber materials such as annual plants, minerals and additives are in addition used as raw material in paper production (Ervasti, 2016).

One of the largest forest products imported into Nigeria is pulp and paper products. This was due to the stability experienced in the global pulp and paper market. Therefore, developing capacities of pulp and paper were not of necessity (Egbewole \& Rotowa, 2017). However, due to the expansion of the global market, the market for pulp and paper began to increase. In order to make use of available raw materials and reduce foreign exchange expenditure, to protect local consumers from the high import prices, develop local industry to promote national industrial development aspirations and provide employment for its population, developing countries began to engage in pulp and paper manufacturing (Picornelli, 1984; Egbewole \& Rotowa, 2017).

The term 'fibre' in anatomical sense refers to the sclerenchymatous fibres, which serve primarily as support to the plant. In an industrial sense, it includes sclerenchymatous fibres, tracheids and vessels (Anon, 2012; Hellgren, 2003). The quantity and properties of fibres, affect the suitability of tree species and their genetic entries as a raw material for mechanical wood processing and pulp and paper production (Peltola et al., 2009). The pulp and paper quality tend to relate closely to fibre dimensions with particular reference to tracheids and libriform fibres, as it is mainly on the basis of fibre dimensions that softwood pulp is in greater demand than hardwood pulp (Rydholm, 1967).

Researches had been carried out on Gmelina arborea, and have been found suitable for making low grade paper which has found tremendous usage in the newspaper and packaging industries (Chittenden \& Rotibi, 1962; Ademiluyi \& Okeke, 1979; Kpikpi \& Olatunji, 1990; Ajuziogu, Ojua, $\&$ Aina, 2019). For this reason, the government of Nigeria in the 1960's established a pulping mill at Oku-Iboku in Akwa-Ibom State which processes G. arborea pulp for local consumption. Apart from G. arborea, there are other fastgrowing plant species whose fibre characteristics are not yet known. In order to relieve the pressure and demand on $G$. arborea, there is the need to assess the paper-making potentials of these tree species.

\section{OBJeCtIVES}

The objective of this present study was to characterize and compare the fibres of four tree species $-P$. biglobosa, $A$. indica, A. boonei and C. siamea commonly found in the Southeastern part of Nigeria to G. arborea, with the intention to elucidating their suitability for the pulp and paper industry.

\section{MATERIALS AND METHODS}

\section{Sample collection}

The trunk wood samples used in this study were collected from the Botanic garden of the University of Nigeria, Nsukka. Ten samples were randomly collected at different positions within the breast height of each tree that was felled. The sampling was carried out using a chainsaw during a thinning exercise. The trees from where samples were collected were reliably identified based on their morphological and floral characteristics as described by Keay, Onochie and Stanfield (1964). The plant species and their families are given in table 1. 
TABLE 1. Plant species and families.

\begin{tabular}{cc}
\hline Plant Species & Family \\
\hline Parkia biglobosa (Jacq.) Bent & Mimosaceae \\
Gmelina arborea (Roxb.) & Verbenaceae \\
Alstonia boonei (Lam) & Apocynaceae \\
Cassia siamea Lam. & Caesalpinaceae \\
Azadirachta indica. A. Juss. & Meliaceae \\
\hline
\end{tabular}

\section{Maceration of wood sample}

The study was conducted in the Plant Anatomy Laboratory in the Department of Plant Science and Biotechnology, University of Nigeria, Nsukka, Enugu State- Nigeria. The Schultze method of maceration as adopted by Kpikpi (1992) was used. This involved splitting the wood samples into small pieces, about the size of a matchstick, to expose large surface areas of contact between the wood and chemicals used, in order to facilitate the maceration process. A quantity of material was chipped such that enough pulp was obtained for evaluation. The samples from the different trees were placed separately into five long Borax test tubes that were well labelled. To each of these test tubes, $2 \mathrm{~g}$ Potassium chlorate (v) $\left(\mathrm{KClO}_{3}\right)$ crystals and then $10 \mathrm{ml}$ of concentrated Trioxonitrate ( $\mathrm{v}$ ) acid $\left(\mathrm{HNO}_{3}\right)$ were added. The test tubes were then placed in a test tube rack and allowed to stand for about 30 minutes to enable the samples to react very well in the solution until they became softened and bleached. The Potassium trioxochlorate (v) acts as a powerful oxidizing agent capable of causing instant reaction with concentrated $\mathrm{HNO}_{3}$ to cause maceration. The maceration process was to dissolve the middle lamella which includes the lignin holding the plant cells together.

At the end of the reaction, excess solution was drained off and the softened pulp washed several times with tap water to prevent further reaction, while making sure no fibres were lost in the process. The washed fibres were then transferred into well-lableled specimen bottles and two drops of phenol and glycerine added to prevent moulding and remove air bubbles respectively. The wood fibres were stained with safranin to render the lignified wall more visible under the microscope.

\section{Measurement of fibre dimensions}

Measurement of fibre dimensions was done using a compound microscope to which an eye-piece micrometer was fitted. The dimensions measured were the fibre length (L), fibre diameter (D); fibre cell wall thickness (C) and fibre lumen diameter (l). The measurements were taken at $\mathrm{x} 400$ magnification in determining the fibre cell wall thickness and lumen diameter, while the fibre length was taken at x100 magnification. The eye-piece micrometer was calibrated using a stage micrometer. Fifteen measurements of the fibre dimensions were taken, and derived fibre values- Runkel ratio (RR), Slenderness ratio (SR) and Coefficient of flexibility (CF), worked out as follows:

- Runkel ratio $=2 C / l$

- Coefficient of flexibility $=l / D$

- Slenderness ratio $=L / D$

\section{Where}

$\mathrm{C}=$ Cell wall thickness

$1=$ Fibre lumen diameter

$\mathrm{D}=$ Fibre diameter

$\mathrm{L}=$ Fibre length

\section{RESULTS}

The analysis of variance shows that significant difference exists in the fibre length (L), fibre diameter (D); fibre cell wall thickness (C) and fibre lumen diameter (I), Runkel ratio (RR), and Coefficient of flexibility (CF) at varied probability levels. However, the Slenderness ratio (SR) was not significantly $(\mathrm{P}>0.05)$ different across plant species (Table 2). The results as presented in table 3 shows that there is no significant difference between the fibre lengths of $G$. arborea and $A$. boonei, while they both differ significantly from those of A. indica, P. biglobosa and C. siamea. However, the fibre lengths of $A$. indica, P. biglobosa and C. siamea are statistically the same. The fibre diameter ranged from $0.0236 \mathrm{~mm}$ to $0.0456 \mathrm{~mm}$ across the different species whereby $A$. boonei recorded significantly $(\mathrm{P}<0.05)$ the widest fibre diameter $(0.0456 \mathrm{~mm} \pm 0.00369 \mathrm{~mm})$ while $C$. siamea had the smallest fiber diameter $(0.0236 \mathrm{~mm} \pm 0.00097 \mathrm{~mm})$ (Table 3). 
TABLE 2. Analysis of variance mean square values.

\begin{tabular}{cc}
\hline Parameter & Mean square \\
\hline Fibre length & $1.33^{* * *}$ \\
Fibre diameter & $0.0010^{* * *}$ \\
Fibre lumen diameter & $0.0020^{* * *}$ \\
Cell wall thickness & $0.0000^{*}$ \\
Runkel ratio & $16.33^{* * *}$ \\
Coefficient of flexibility & $0.22^{* *}$ \\
Slenderness ratio & $452.94^{\mathrm{NS}}$ \\
\hline
\end{tabular}

* = Significant at $P<0.05 ;{ }^{* *}=$ Significant at $P<0.01,{ }^{* * *}=$ Significant at $P<0.001$.

TABLE 3. The mean fibre lengths and diameter of the species.

\begin{tabular}{ccc}
\hline Treatment & Fibre length $(\mathrm{mm})$ & Fibre diameter $(\mathrm{mm})$ \\
\hline G. arborea & $1.54 \pm 0.90^{\mathrm{a}}$ & $0.0396 \pm 0.00183^{\mathrm{b}}$ \\
A. boonei & $1.70 \pm 0.08^{\mathrm{a}}$ & $0.0456 \pm 0.00369^{\mathrm{a}}$ \\
A. indica & $1.15 \pm 0.04^{\mathrm{b}}$ & $0.0276 \pm 0.00110^{\mathrm{c}}$ \\
P. biglobosa & $1.00 \pm 0.05^{\mathrm{b}}$ & $0.0240 \pm 0.00143^{\mathrm{c}}$ \\
C. siemea & $1.14 \pm 0.08^{\mathrm{b}}$ & $0.0236 \pm 0.00097^{\mathrm{c}}$ \\
F-LSD $(\mathrm{P}<0.05)$ & 0.198 & 0.0048 \\
\hline
\end{tabular}

*significant means are represented with different alphabets on each vertical array.

The mean fibre lumen diameters of the species are given in table 4. The result shows that there is no significant $(\mathrm{P}<$ $0.05)$ difference between the fibre lumen diameters of $G$. arborea and $A$. boonie, but these two species differ significantly from $A$. indica, $P$. biglobosa and C. siamea. The fibre cell wall thickness ranged from $0.0064 \mathrm{~mm}$ to 0.0089 $\mathrm{mm}$ with $C$. siamea recording the thickest fibre which was however not significantly $(\mathrm{P}>0.05)$ different from the fibre thickness recorded by $G$. arborea and $A$. boonie (Table 4).

The mean fibre Runkel ratios of the species as presented in table 5 shows that the Runkel ratios of three species namely: Gmelina arborea, Alstonia boonie and Azadirachta indica are statistically the same. Nevertheless, the Runkel ratio of Casia siamea differed significantly from all the species. The coefficients of flexibility of $G$. arborea and $A$. boonei were similar, while they both differ significantly from those of $A$. indica, P. biglobosa and C. siamea. However, the slenderness ratio was not significantly different across species (Table 5).

\section{DISCUSSION}

The fibre length of $G$. arborea of $1.5 \mathrm{~mm}$ average observed in the present study corroborates the report of Moya, Tomazelo and Canessa (2007), therefore strengthening the reliability of our data. The result from the present study on the fibre length shows that the average fibre length $(\mathrm{L})$ of A. boonei was $1.70 \mathrm{~mm}$. In accordance with the classification of Metcalfe and Chalk (1983), fibres above $1.6 \mathrm{~mm}$ in length are long. Therefore, $A$. boonei has long fibres, while the fibre of other wood species studied were short. The association between fibre length and pulp and paper properties cannot be overstressed. Fibre length influences a large amount of the pulp strength properties; positive relationships have been observed between fibre length and tear index for Pinus radiate and P. elliotttii (Wright and Sluis-Cremer, 1992), burst 
TABLE 4. The mean fibre lumen diameters and cell wall thickness of the species

\begin{tabular}{ccc}
\hline Treatment & Fibre lumen diameter $(\mathrm{mm})$ & Fibre cell wall thickness $(\mathrm{mm})$ \\
\hline G. arborea & $0.0266 \pm 0.00203^{\mathrm{a}}$ & $0.0077 \pm 0.00038^{\mathrm{ab}}$ \\
A. boonei & $0.0293 \pm 0.00371^{\mathrm{a}}$ & $0.0087 \pm 0.00084^{\mathrm{a}}$ \\
A. indica & $0.0122 \pm 0.00103^{\mathrm{b}}$ & $0.0072 \pm 0.00093^{\mathrm{b}}$ \\
P. biglobosa & $0.0098 \pm 0.00109^{\mathrm{b}}$ & $0.0064 \pm 0.00058^{\mathrm{b}}$ \\
C. siemea & $0.0079 \pm 0.00106^{\mathrm{b}}$ & $0.0089 \pm 0.00063^{\mathrm{a}}$ \\
F-LSD $(\mathrm{P}<0.05)$ & 0.0067 & 0.0013 \\
\hline
\end{tabular}

*significant means are represented with different alphabets on each vertical array

TABLE 5. The mean fibre Runkel ratios, coefficient of flexibility and slenderness ratio of the species.

\begin{tabular}{cccc}
\hline Treatment & Runkel ratios & Coefficient of flexibility & Slenderness ratio \\
\hline G. arborea & $0.624 \pm 0.572^{\mathrm{c}}$ & $0.677 \pm 0.045^{\mathrm{a}}$ & $40.0175 \pm 3.044177$ \\
A. boonei & $0.768 \pm 0.127^{\mathrm{c}}$ & $0.643 \pm 0.052^{\mathrm{a}}$ & $45.7191 \pm 7.942999$ \\
A. indica & $1.228 \pm 0.107^{\mathrm{bc}}$ & $0.438 \pm 0.031^{\mathrm{b}}$ & $42.5047 \pm 2.197944$ \\
P. biglobosa & $1.464 \pm 0.212^{\mathrm{b}}$ & $0.458 \pm 0.040^{\mathrm{b}}$ & $34.4600 \pm 4.289465$ \\
C. siemea & $3.227 \pm 0.578^{\mathrm{a}}$ & $0.428 \pm 0.098^{\mathrm{b}}$ & $48.8097 \pm 3.483221$ \\
F-LSD $(\mathrm{P}<0.05)$ & 0.81 & 0.164 & $\mathrm{NS}$ \\
\hline
\end{tabular}

*significant means are represented with different alphabets on each vertical array..

strength (Ona et al. 2001), tear strength (Haygreen and Bowyer 1996) and folding endurance (Ona et al. 2001). Fibre length has also been shown to be principally of importance to tearing resistance (Wangaard \& Williams 1970). According to Gallay (1962) and Ademiluyi and Okeke (1979), greater fibre length conforms to higher tearing resistance of paper, which was attributed to stress dissipation; the longer the fibre, the larger the area over which the stress was dissipated. However, longer fibres tended to give a more open and less uniform sheet structure (Ogunleye, Fuwape, Oluyege, Ajayi, \& Fabiyi, 2017). This observation indicates that papers produced from wood fibres of $A$. boonei is likely to have high tear resistance than those from the other wood samples studied.

The fibre diameter of G. arborea observed in this study was higher than that reported by Moya et al. (2007) and Ogunkunle (2010). Okereke (1962) reported that fibre with large diameter and broad lumen diameter ensures better collapsibility and therefore provides enough bonding surface during paper production. This implies that $A$. boonei with the largest fibre diameter will provide better inter fibre bonding while C. siamea will provide the least. More so, Palmer (1986) pointed out that the thinner the cell wall thickness the better the fibre for papermaking, as fibres with thin walls collapse easily and provide effective bonding surface during papermaking.

The derived fibre values are usually applied as parameters for the assessment hardwood fibres (Okereke, 1962; Ademiluyi \& Okeke, 1979; Kpikpi, 1992). These values are Runkel ratio (RR), slenderness ratio (SR), and coefficient of flexibility (CF). The lower the Runkel ratio especially when it is less than 1 , the better for papermaking (Dutt, Upadhyaya, Singh, \& Tyagi, 2009; Ona et al. 2001; Ogunleye et al., 2017). Based on this, G. arborea and A. boonei are considered fit for papermaking. Chittenden and Rotibi (1962) pointed out that papers made from fibre with high Runkel ratio are porous and stiff. However, fibres with relatively thin walls collapse more readily in the paper sheet 
formation. This leads to strong inter-fibre bonding thus increasing the tear resistance of the paper.

The standard values for hardwood and softwoods are $0.55-0.70$ and 0.75 respectively, whereby fibres having coefficient of flexibility ranging from $0.50-0.75$ are considered as highly elastic fibres (Ogunleye et al., 2017). This indicates the suitability of $A$. boonei as compared to $G$. arborea for papermaking. Similarly if the postulate by Ademiluyi and Okeke (1979) holds, that the higher the slenderness ratio, the greater the tear resistance of the paper, then it is reasonable to say that from our data all the tree species will show the good tear resistance as compared to $G$. arborea.

\section{CONCLUSIONS}

The results of the investigations showed that the wood fibres of $A$. boonei and $G$. arborea among the other three species are the most suitable for papermaking. Working with the principles that the fibres with the lowest Runkel ratio and highest coefficient of flexibility make the strongest papers, the order of quality of the species studied is: $G$. arborea $=A$. boonei $=P$. biglobosa $>A$. indica $>$ C. siamea . In this respect $G$. arborea is the best option for paper making followed by $A$. boonei. Since there is no significant difference between $G$. arborea and $A$. boonei in all the fiber dimensions, and using $G$. arborea as standard since it has been established as a papermaking hardwood species, it may be concluded that $A$. boone $i$ is another pulp wood with good paper-making potentials apart from the already known G. arborea. Also, if fibre length is taken into consideration, $A$. boonei shows great potential as a pulping species.

\section{REFERENCES}

Ademiluyi, E. O. \& Okeke, R. E. (1979). Studies on specific gravity and fibre characterization of Gmelina arborea in some Nigerian plantation. Nigerian Journal of Science, 13, 231-238.

Ajuziogu, G. C., Ojua, E. O. \& Aina, D. O. (2019). Comparative papermaking potentials of three species from the Verbenaceae and Lamiaceae family. Asian Journal of Research in Botany, 2(4), 1-5.
Chittenden, A. E. \& Rotibi, J. O. (1962). Studies on the suitability of Nigerian raw materials for pulp making, Gmelina arborea. Research Report 17, Federal Ministry of Commerce and Industry.

Dutt, D., Upadhyaya, J. S., Singh, B., \& Tyagi C. H. (2009). Studies on Hibiscus cannabinus and Hibiscus sabdariffa as an alternative pulp blend for softwood: An optimsation of kraft delignification process. Industrial Crops and Products, 29(1), 16-26.___doi: 10.1016/j.indcrop.2008.03.005

Egbewole, Z. T. \& Rotowa, O. J. (2017). Effects of Declining Paper Industry on Nigeria Economy and the Way Forward. American Journal of Agriculture and Forestry, 5(6), 181-187. doi: 10.11648/j.ajaf.20170506.11

Ervasti, I. (2016). Wood fiber contents of different materials in the paper industry material chain expressed in roundwood equivalents (RWEs). Silva Fennica, 50(4), 1611 - 1632. doi: 10.14214/sf.1611

Ezeudu, O. B., Agunwamba, J. C., Ezeasor, I. C. \& Madu, C. M. (2019). Sustainable production and consumption of paper and paper products in Nigeria: A review. Resources, 8(1), 1-23. doi: $10.3390 /$ resources 8010053

Gallay W. (1962). In Bolam, F. (Ed.) The formation and structure of paper. (Technical Section of British Paper and Board Makers' Association), London, pp. 491-535.

Keay, R. W. J., Onochie, C. F. A., \& Stanfield, D. P. (1964). Nigerian Trees (Vol. 11). Nigeria: Federal Department of Forest Research Ibadan.

Kpikpi, W. M. \& Olatunji, A. O. (1990). Wood anatomy consideration in deciding suitability of some Nigerian hardwood for pulp and paper production. Nigerian Journal of Botany, 3, 137-150.

Kpikpi, W. M. (1992). Wood structure and paper making potentials of Recinodendron beudelotti and Albizia sygia in relation to Gmelina arborea. Nigerian Journal Botany, 5, 41-50.

Metcalfe, C. R. \& Chalk, L. (1989). Anatomy of the Dicotyledons Vol. II (2nd ed). Oxford University Press.

Ogunkunle, A. T. J. (2010). A quantitative modelling of pulp and paper making suitability of Nigerian hardwood species. Advances in Natural and Applied Sciences, 4(1), 14-21.

Ogunleye, B. M., Fuwape, J. A., Oluyege, A. O., Ajayi, B. \& Fabiyi, J. S. (2017) Evaluation of fiber characteristics of Ricinodedron beudelotii (Baill, Pierre Ex Pax) for pulp and paper making. International Journal of Science and Technology, 6(1), 634-641.

Okereke, O. O. (1962). Studies on the fibre dimension of some Nigerian timber and other raw materials (Part 1). Research Report 16, Federal Ministry of Commerce and Industry. 
Ona, T., Sonoda, T., Ito, K., Shibata, M., Tamai, Y., Kojima, Y., Ohshima, J., Yokota, S. \& Yoshizawa, N. (2001). Investigation of relationships between cell and pulp properties in Eucalyptus by examination of within-tree variations. Wood Science and Technology, 35, 229-243. doi: 10.1007/s002260100090

Palmer, E. R. (1973). Gmelina arborea as a potential source of hardwood pulp. Tropical Science, 15, 243-260.

Peltola, H., Gort, J., Pulkkinen, P., Zubizarreta Gerendiain, A., Karppinen, J. \& Ikonen, V-P. (2009). Differences in growth and wood density traits in Scots pine (Pinus sylvestris L.) genetic entries grown at different spacing and sites. Silva Fennica, 43(3), 339-354. doi: 10.14214/sf.192

Picornelli, P. M. (1984): Protecting new pulp and paper industries: an opinion from developing countries. Unasylva, 144, 54-62.

Moya R., R., Tomazelo F., M., \& Canessa A., E. (2007). Fiber morphology in fast growth Gmelina arborea plantations. Madera y Bosques, 13(2), 3-13. doi: 10.21829/myb.2007.1321225

Rydholm, S. A. (1967). Pulping Process. New York: John Willey-Sons Ltd.

Wangaard F. F. \& Williams D. L. (1970). Fibre length and fibre strength in relation to tearing resistance of hardwood pulp. TAPPI Journal, 5(11), 2153-2154.
Wright, J. A. \& Sluis-Cremer, H. J. (1992). Tracheid morphology and pulp and paper strength traits of Pinus taeda and P. patula at age 17 years in South Africa. TAPPi Journal, 75(5), 183-187.

\section{Received: 24 May 2019}

Accepted: 21 Janyuary 2020

Published: 26 June 2020

This paper must be cited as:

Ajuziogu, G. C., Ojua, E. O., Abu, N. E., Onyeke, C. C., Ayogu, V. O., Nweze, A. E., \& Nworie, S. (2020). Comparative studies of fibres of woody species selected in relation to their papermaking potentials. Madera y Bosques, 26(2), e2621968. doi: 10.21829/myb.2020.2621968

Madera y Bosques by Instituto de Ecología, A.C. is distributed under a Creative Commons Licence Attribution-NonCommercial-ShareAlike $\quad 4.0$ Internacional. 